\title{
Islet Cell 512 Antibody Measurement
}

National Cancer Institute

\section{Source}

National Cancer Institute. Islet Cell 512 Antibody Measurement. NCI Thesaurus. Code C81985.

The determination of the amount of islet cell 512 antibody present in a sample. 